\title{
WORD-ENDS AND METRICAL BOUNDARIES IN ANCIENT IAMBIC TRIMETER OF COMEDY
}

\author{
Maria-Kristiina Lotman
}

\section{Introduction}

It is generally known that word-ends in a verse tend to accumulate in certain positions, while they are avoided in other positions. Researches concerning regularities in occurrences of word-ends are quite common in verse theory (incl. ancient metrics). Thus, as for the inheritance of ancient Greek poetry, hexameter as well as lyric and tragic iamb has been thoroughly analysed: the positions of main caesuras and bridges are established. But at the same time the occurrences of word-ends in iambic trimeter of comedy have not been given enough attention. In the present research an attempt is made to correct such deficiency and to describe the most important statistical regularities in this verse ${ }^{1}$.

We proceed from the standpoint that both in ancient Greek and Latin the deep structure of iambic trimeter is following:

\section{$\& \& \& A B \& A B \& \& A B \& A B \& \& A B \& A B \& \& \&$}

(where A and B mark different metrical positions, \& verse feet boundaries, \&\& dipodic boundaries and $\& \& \&$ verse boundaries).

The following quantitative-syllabic correspondence rules are applied here:

1) one short syllable or a sequence of two short syllables corresponds to A position, but the latter can occur if, and only if, B position is filled with one syllable;

2) one short syllable, one long syllable or a sequence of two syllables corresponds to \&A position, but the latter can occur if, and only if, B position is filled with one syllable;

3) one long syllable or a sequence of two syllables corresponds to B position, but the latter can occur if, and only if, A position is filled with one syllable.

Thus, we treat meter as an abstract sequence of elements that can be separated into smaller units (foot, dipody). The main purpose of the analysis is to study the relationship between metrical boundaries in deep structure and word-ends in surface structures that occur when the meter is realised.

\footnotetext{
${ }^{1}$ The research is based on iambic trimeters in following texts: "The Clouds" and "The Frogs" by Aristophanes, "The Peevish Fellow" and "Epitrepontes" by Menander, "Pseudolus" and "Comedy of Asses" by Plautus, "The Lady of Andros" and "The Brothers" by Terence.
} 
In analysing the relationship between metrical boundaries and word-ends we pay special attention to the role of word-ends in verse structure: i.e. how often they coincide with metrical boundaries and whether they function as a reinforcement for these boundaries, or vice versa, as an enfeeblement.

\section{Word-ends after B positions}

Ancient iambic trimeter is dipodic by its nature. In order to compare the verse feet boundaries with dipodic boundaries, it is necessary to collate the occurrences of wordends after the second and fourth verse foot with the occurrences of word-ends after the first and third foot. The results of the study are presented in the following table.

Tab. 1. The co-occurrences of word-ends and boundaries after B positions $(\% \%)$

\begin{tabular}{|l|l|r|r|r|r|r|r|}
\hline Author & Comedy & 1.foot & 2. foot & 3. foot & 4. foot & 5. foot & 6. foot \\
\hline Aristophanes & "The Clouds" & 62,2 & 40,8 & 39,8 & 56,8 & 35,4 & 100 \\
\hline & "The Frogs" & 61,2 & 40,2 & 40,4 & 59 & 47,4 & 100 \\
\hline Menander & "The Peevish Fellow" & 61,8 & 43,2 & 45,6 & 47 & 55,6 & 100 \\
\hline & "Epitrepontes" & 52,2 & 41 & 48,8 & 49,8 & 53,2 & 100 \\
\hline Plautus & "Pseudolus" & 49 & 22,2 & 29,8 & 43,4 & 48,4 & 100 \\
\hline & "Comedy of Asses" & 47,4 & 25,6 & 35,6 & 43,2 & 39,2 & 100 \\
\hline Terence & "The Brothers" & 42,2 & 33,4 & 30,8 & 43,2 & 48,6 & 100 \\
\hline & "The Lady of Andros" & 44,2 & 43,8 & 35,2 & 44,2 & 43,4 & 100 \\
\hline
\end{tabular}

It reveals that in Aristophanic comedies "The Clouds" and "The Frogs" the greatest cooccurrence of word-ends and metrical boundaries is after the first verse foot (if we compare it with the data of the whole verse, then we can see that it is exceeded only by the occurrences of word-ends after the first position of the third foot, which is commonly known as penthemimeral caesura). The smallest number of co-occurrences appears after the second and the third verse foot: the latter can be explained by the tendency to avoid the distribution of verse into two equal symmetrical parts. According to this principle the change of character (antilabe) occurs extremely rarely in this position. At the same time word-ends occur quite often after the fourth foot, which is remarkable, considering, on the one hand, the fact that hephthemimeral caesura is in the same foot, and on the other hand the fact that we are dealing here with dipodic boundary (we can not see the number of word-ends on dipodic boundaries exceeding $50 \%$ in other analysed texts). In the position after the fifth foot we note the difference between "The Clouds" and "The Frogs": in the first comedy word-end appears more seldom in this place. The typical placing of word-ends after verse feet in Aristophanic verse is illustrated by the following ideal scheme: AB\#ABABAB\#ABAB (where A and B mark different metrical positions, \# marks word-ends). E.g. Arist. Nub. 67

$$
\begin{aligned}
& \text { A B \# A B A B A A \# A B A B }
\end{aligned}
$$

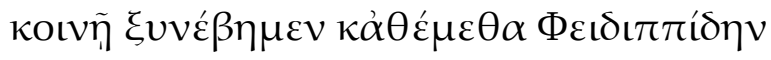


or Arist. Ran. 203

$$
\begin{aligned}
& \text { А В \# А } \\
& \dot{\varepsilon} \lambda \tilde{\alpha} \varsigma \pi \text { В А }
\end{aligned}
$$

The statistics of Menander's plays are not as similar to each other as we saw in the case of Aristophanic texts. In the earlier comedy "The Peevish Fellow" we note the tendency of Aristophanes to frequent co-occurrences of word-ends and metrical boundaries after the first foot. At the same time they occur more rarely after the second foot and more often after the fifth foot. Unlike the earlier author, Menander places word-ends after the third foot freely. He allows changes of characters there as well. The co-occurrences of wordends and metrical boundaries are presented in the following ideal scheme: AB\#ABABABAB\#AB, e.g. Men. Dysc. 32

$$
\begin{aligned}
& \text { A B \# A } \text { B A } \text { B A } \text { B A \# B A B }
\end{aligned}
$$

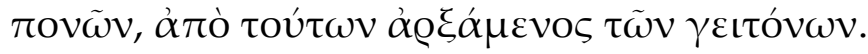

In "Epitrepontes" we cannot see the salient placing of word-ends any more, which is characteristic to Aristophanes. The greatest number of co-occurrences is after the fifth verse foot, which is quite similar to the data characterising the position after the first foot. There is a tendency to avoid word-ends after the second foot. All these regularities of "Epitrepontes" are reflected in the following verse (Men. Epitr. 48):

$$
\begin{aligned}
& \text { A B \# A B A B A B A B \# A B }
\end{aligned}
$$

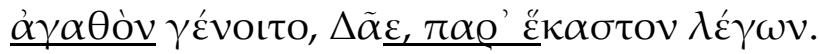

According to these results we can conclude that in iambic trimeter of Greek comedy word-ends occur on metrical boundaries preferably after the first, the fourth (Aristophanes) and the fifth (Menander) verse foot. But at the same time we do not see the direct avoidance of word-ends in other positions, although there are traces of obviating the diaeresis, which separates verse into two equal parts (the typical tendency of tragedy). As there is no accumulation of word-ends on metrical boundaries, we cannot say that word-ends have a special function in dividing a verse, but vice versa, in the central part of verse word-ends tend to occur inside verse feet rather than after them, i.e. syntactic boundaries function against metrical boundaries.

Such regularities become even deeper in Roman comedy. In plays by Plautus, "Pseudolus" and "Comedy of Asses", the number of co-occurrences between word-ends and metrical boundaries is smaller. They occur most often after the first and the fifth foot, most seldom after the second and the third foot. Such preferences are similar to the data of Menander, but accumulations or avoidances of word-ends in certain positions appear a lot more contrastingly. If we compare these data with that of the word-ends inside verse feet, we can see that for example in "Pseudolus", there is an extremely big difference in occurrences of word-ends after the second verse feet and the adjacent first position of the 
third feet: accordingly $20 \%$ and $80 \%$. Thus, the ideal scheme of word-ends coinciding metrical boundaries in Plautus' verse is AB\#ABABABAB\#AB, e.g. Plaut. Trin. 208

\author{
A B \# A B A B A B A B \# A B \\ sciunt quod Iuno fabulatast cum Iove
}

In Terence's comedies "The Brothers" and "The Lady of Andros", the preferences are analogical to Plautus: word-ends occur more often after the first and the fifth foot. The lowest degree of co-occurrences is after the third foot: it seems that it is generally more characteristic to Roman comedians to follow the rule of avoiding diaeresis in the centre of the verse, which was in force in Greek lyrics and tragedy. The ideal scheme reflecting the occurrences of word-ends after verse foot in Terence's verse is following: AB\#ABABAB\#ABAB, e.g. Ter. Adelph. 67
A B \# A
B A B A B \# A B A B
vi quod fit, quam illud quod amicitia adiungitur

or Ter. Andr. 65

\title{
A B \# A B A A B A B\# A B A B
}

numquam praeponens se illis: ita ut facillume.

It is remarkable that in Latin iambic trimeter, word-ends do not usually coincide with boundaries of verse feet in the central part of verse. This is clearly the result of conflict between metrical boundaries and syntactic boundaries. It is also essential to notice that the lowest rate of occurrences of word-ends is on dipodic boundaries.

Thus, inside of verse we note the tendency of word-ends to function against metrical boundaries. But the analysis of verse boundaries shows the opposite mechanism: the occurrence of word-end in the end of verse is constant and, in addition to that, syntactic boundaries (i.e. phrase boundaries, sentence boundaries, character changes) accumulate there. Accordingly, position B\&\&\& is marked with syntactic means as well (cf. tab. 2.). We can see that most of the changes of characters, phrase ends and sentence ends occur after the sixth foot. The proportions of occurrences of syntactic boundaries are different in different authors: Aristophanes prefers to place there changes of characters, Menander prefers ordinary word-ends and phrase boundaries, both Roman authors prefer phrase boundaries. 
Tab. 2. The frequency of word-ends after B\&\&\& position (\%\%)

\begin{tabular}{|c|c|c|c|c|c|c|c|}
\hline Author & Comedy & & $\begin{array}{l}\text { Word- } \\
\text { end }\end{array}$ & $\begin{array}{l}\text { Phrase- } \\
\text { end }\end{array}$ & $\begin{array}{l}\text { Sentence- } \\
\text { end }\end{array}$ & Antilabe & Sum \\
\hline \multirow[t]{4}{*}{ Aristophanes } & "The Clouds" & anapaest & 0 & 0,2 & $\begin{array}{r}0 \\
\end{array}$ & 0,2 & 0,4 \\
\hline & & iamb & 17,6 & 22,8 & 15,8 & 43,4 & 99,6 \\
\hline & "The Frogs" & anapaest & 0 & 0,2 & 0 & 0 & 0,2 \\
\hline & & iamb & 22,2 & 21,8 & 12,6 & 43,2 & 99,8 \\
\hline \multirow[t]{4}{*}{ Menander } & "The Peevish Fellow" & anapaest & 0 & 0 & 0,2 & 0 & 0,2 \\
\hline & & iamb & 55,4 & 20,2 & 12,4 & 11,8 & 99,8 \\
\hline & "Epitrepontes" & anapaest & 0 & 0 & 0 & 0 & 0 \\
\hline & & iamb & 52,6 & 22,4 & 13,4 & 11,6 & 100 \\
\hline \multirow[t]{4}{*}{ Plautus } & "Pseudolus" & anapaest & 0,4 & 0,8 & 0,8 & 1,2 & 3,2 \\
\hline & & iamb & 17,2 & 34,8 & 18,8 & 26 & 96,8 \\
\hline & "Comedy of Asses" & anapaest & 0,4 & 0,2 & 1 & 1,2 & 2,8 \\
\hline & & iamb & 19 & 32,2 & 19,2 & 26,8 & 97,2 \\
\hline \multirow[t]{4}{*}{ Terence } & "The Brothers" & anapaest & 2,8 & 1,8 & 1 & 1,2 & 6,8 \\
\hline & & iamb & 25,4 & 33,6 & 17,6 & 16,6 & 93,2 \\
\hline & "The Lady of Andros" & anapaest & 0,6 & 1 & 0,4 & 0,8 & 2,8 \\
\hline & & iamb & 21,6 & 31,4 & 20,2 & 24 & 97,2 \\
\hline
\end{tabular}

Consequently we can say that B\& and B\&\& positions are not usually followed by wordends. At the same time B\&\&\& position is constantly followed by word-end, syntactically strong boundaries serve the purpose to mark the end of verse, which is supported by the bridge in the sixth foot, as well.

\section{Word-ends after A positions}

Analysing the occurrences of word-ends inside verse feet, we take special interest in positions between elements A and B (in realised verse anceps/breve and princeps). The data are presented in tab. 3 .

Tab. 3. The frequency of word-ends after A positions ( $\% \%)$

\begin{tabular}{|l|l|c|c|c|c|c|c|}
\hline \multicolumn{1}{|c|}{ Author } & Comedy & 1. foot & 2 . foot & 3 . foot & 4 . foot & 5 . foot & 6 . foot \\
\hline Aristophanes & "The Clouds" & 48 & 41,4 & 77,4 & 48,2 & 51,6 & 9,4 \\
\hline & "The Frogs" & 51,6 & 46,2 & 73,4 & 53,6 & 37,8 & 9 \\
\hline Menander & "The Peevish Fellow" & 29,8 & 35 & 66 & 47,2 & 53,2 & 13,8 \\
\hline & "Epitrepontes" & 37,2 & 40,2 & 67,6 & 49,4 & 51,8 & 15,6 \\
\hline Plautus & "Pseudolus" & 61,6 & 49,8 & 92,2 & 61,8 & 41,4 & 1,2 \\
\hline & "Comedy of Asses" & 54,8 & 51,2 & 85 & 61,6 & 50,6 & 2,6 \\
\hline Terence & "The Brothers" & 51 & 65,8 & 81,8 & 64,6 & 66 & 5,2 \\
\hline & "The Lady of Andros" & 59,8 & 55,6 & 76,8 & 68 & 58 & 4,6 \\
\hline
\end{tabular}


As for Greek playwrights, there are two conspicuous tendencies: relatively great number of word-ends in the third foot, which results in regular penthemimeral caesura, and the bridge in the sixth foot - the last word in a verse has usually two or more syllables. It is also interesting that in the position of lex Porsoniana in the fifth foot the number of word-ends exceeds $50 \%$. While Aristophanes places word-ends in other positions of verse quite homogeneously, Menander seems to prefer in the first half of verse words that include both anceps and princeps. E.g. Men. Dysc. 101
A

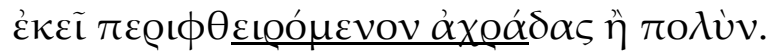

If we compare the frequency of word-ends after B position with the frequency after A position, the latter appears to be a little higher already in Greek texts. In Roman comedy such tendencies become deeper. The number of verses with penthemimeral caesura exceeds $80 \%$, in "Pseudolus" by Plautus even 92\% (in Greek tragedy the frequency of caesuras in this position was also extremely high, cf. West 1982: 82-83). The position between anceps and princeps in the third foot is at the same time the most preferable place for phrase and sentence ends that occur inside verse. The bridge in the sixth foot becomes almost obligatory, e.g. Plaut. Pseud. 89
A B A
B A
B A B A B A B
mihi emere. PS. quam ob rem? CA. qui me faciam pensilem

or Ter. Adelph. 827
A B A
B A B A
B A B
A B
ita ut volumus. video eos sapere, intellegere, in loco.

While for Plautus the second important position for word-ends is hepthemimeral caesura, Terence places word-ends equally in the second and the fifth foot which, in Greek lyrics and tragedy, is regulated with Porson's law (it is obvious that lex Porsoniana in Roman verse is of no importance whatsoever, while in Greek comedy the avoidance of it may have resulted from conscious denial of verse technique of tragedy).

\section{The number of words in a verse}

The present research includes also the average number of words in a verse, as the number of word boundaries depends directly on it. We will characterise briefly the average number of words in every analysed text and bring forth the regularities as well as the deviations (cf. tab. 4). 
Tab. 4.The number of words in a verse $(\% \%)$

\begin{tabular}{|c|c|c|c|c|c|c|c|c|c|c|}
\hline Author & Comedy & 3 & 4 & 5 & 6 & 7 & 8 & 9 & 10 & 11 \\
\hline \multirow[t]{2}{*}{ Aristophanes } & "The Clouds" & 0,4 & 5 & $\overline{21,4}$ & 33,6 & 23,6 & 12,4 & 2,8 & 0,8 & 0 \\
\hline & "The Frogs" & 1,4 & 4,4 & 20,4 & 28,8 & 25,4 & 15,6 & 3,2 & 0,4 & 0,4 \\
\hline \multirow[t]{2}{*}{ Menander } & "The Peevish Fellow" & 0,2 & 4,6 & $\overline{23,2}$ & 35,2 & 25 & 9,8 & 1,6 & 0,4 & 0 \\
\hline & "Epitrepontes" & 0 & 4,2 & 22,8 & 32,8 & 28 & 10,2 & 1,4 & 0,6 & 0 \\
\hline \multirow[t]{2}{*}{ Plautus } & "Pseudolus" & 0,6 & 4,6 & $\overline{16,4}$ & 32,8 & 29,8 & 11,8 & 2,6 & 1,2 & 0,2 \\
\hline & "Comedy of Asses" & 0,4 & 3,2 & 16,8 & 30,8 & 30,8 & 12,2 & 5,2 & 0,6 & 0 \\
\hline \multirow[t]{2}{*}{ Terence } & "The Brothers" & 0,4 & 3,6 & $\overline{12,4}$ & 26,2 & 31 & 17,6 & $\overline{7,6}$ & 0,8 & 0,4 \\
\hline & "The Lady of Andros" & 0 & 4,2 & 9,6 & 27,2 & 30,6 & 20 & 6,2 & 2 & 0,2 \\
\hline
\end{tabular}

It appears that certain differences between authors occur here as well. We note that in case of Aristophanes' and Menander's iambic trimeter the verse lines which include 5-8 word boundaries prevail: the lines with six words are the most frequent, e.g. Arist. Nub. 25

\section{A B $\begin{array}{llllllllll}\text { A } & \text { B } & \text { A } & \text { B A } & \text { B } & \text { A } & \text { B } & \text { A } & \text { B }\end{array}$}

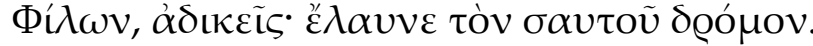

or Men. Dysc. 150

A B A B A B A B A B A B

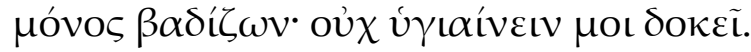

While in Aristophanic comedies we can find lines with three words (there are even seven cases in "The Frogs"), Menander has only one such line ("The Peevish Fellow"). Aristophanes has two times a verse line with 11 words; there is no such precedent in Menander's texts.

The average number of words in Roman trimeter is approximately the same as in Greek trimeter, but proportions are different to some extent. Plautus has the greatest number of verses with six words, e.g. Plaut. Pseud. 404

\section{A B A BA B A B A B A B}

nunc ego poeta fiam: viginti minas,

and only a little fewer verses with seven words, e.g. Plaut. Pseud. 63
A $\quad$ B A B A
$\mathrm{B}$ A $\mathrm{B}$
A B A B

lege: dulce amarumque una nunc misces mihi.

Terence has the greatest number of verses with seven words, e.g. Ter. Andr. 124
A B A B A B
A B A
B A B

quae sit rogo: sororem esse aiunt Chrysidis, 
Note also that the frequency of lines with eight words is rather high. So it appears that Roman trimeter includes averagely more words in comparison with Greek trimeter.

\section{Summary}

We can conclude on basis of data concerning statistical indices of Greek comic trimeter that general tendencies that are common to both authors characterise the first, third and sixth verse foot. In the first foot word-ends occur more after B position than A position; in the third foot, on the contrary, the penthemimeral caesura appears, which results from numerous strong syntactic boundaries; in the sixth foot A position is followed by the bridge and $\mathrm{B}$ position is followed by the constant word-end which coincides with verse end. The realisation of the second and the fourth foot has no statistically relevant differences; at the same time the realisation of the fifth foot depends on author and text: Menander places word-ends more or less equally after both A and B positions, Aristophanes prefers word-ends after A position in "The Clouds", after B position in "The Frogs".

In Roman iambic trimeter, the whole verse is characterised by the clear tendency of word-ends occurring rather after A position than after B position. The only exception here is the sixth foot, which is zeugmatic - analogically to Greek comic trimeter - being conterminous with constant word-end.

Consequently, there are two positions in ancient comic trimeter in which the occurrences of word-ends can be explained by direct influence of metrical boundaries: i.e. in the third and sixth verse foot. The third foot is mostly carried out with syllables that belong to separate words and often to separate phrases. At the same time the cooccurrences between word-ends and metrical boundary of the given foot are avoided in order to obviate the division of a verse line into two quantitatively equal parts. The realisation of the sixth verse foot is determined by verse boundary: it coincides with the obligatory word-end, which is emphasised with the bridge in the sixth foot. 


\section{Selected bibliography}

Beare, W. 1968. The Roman stage. London

Crusius, F., Rubenbauer, H. 1955. Römische Metrik. München.

Drexler, H. 1987. Einführung in die römische Metrik. Darmstadt

Drobisch, M. V. 1866. Ein statistisches Versuch über die Formen des lateinischen Hexameters. Leipzig.

Halporn, J. W., Ostwald, M., Rosenmeyer, T. G. 1962. The meters of Greek and Latin poetry. Oklahoma.

Jalasto, H. 1978. Elementaarstatistika käsiraamat. Tallinn.

Korzeniewski, D. 1989. Griechische Metrik. Darmstadt.

Lotman, M. and Shahverdov, S. 1973. 'Некоторые аспекты теории стиха.' - Сборник статей по вторичным моделирующим системам, Тарту ТГУ, с. 168-175.

Lotman, M. 1998. 'Värsisüsteemidest.' — Akadeemia nr. 9-10, 1k. 1846-1875, 20582078

Maas, P. 1929. Griechische Metrik. 2. Aufl. Leipzig.

West, M. L. 1973. 'Indo-European metre.' - Glotta 51, pp. 161-178.

West, M. L. 1982. Greek metre. Oxford

West, M. L. 1987. Introduction to Greek metre. Oxford 


\section{Appendix}
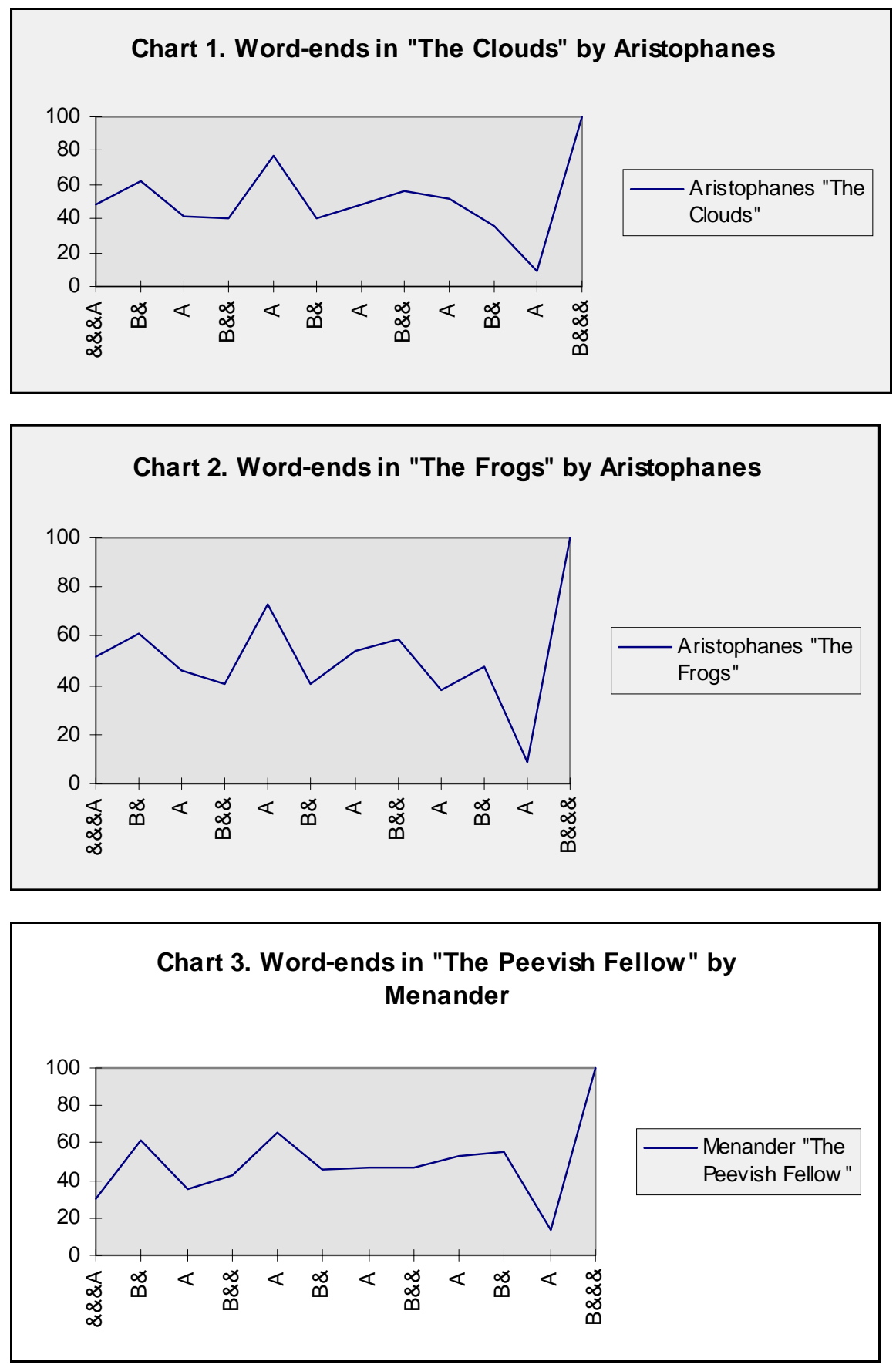

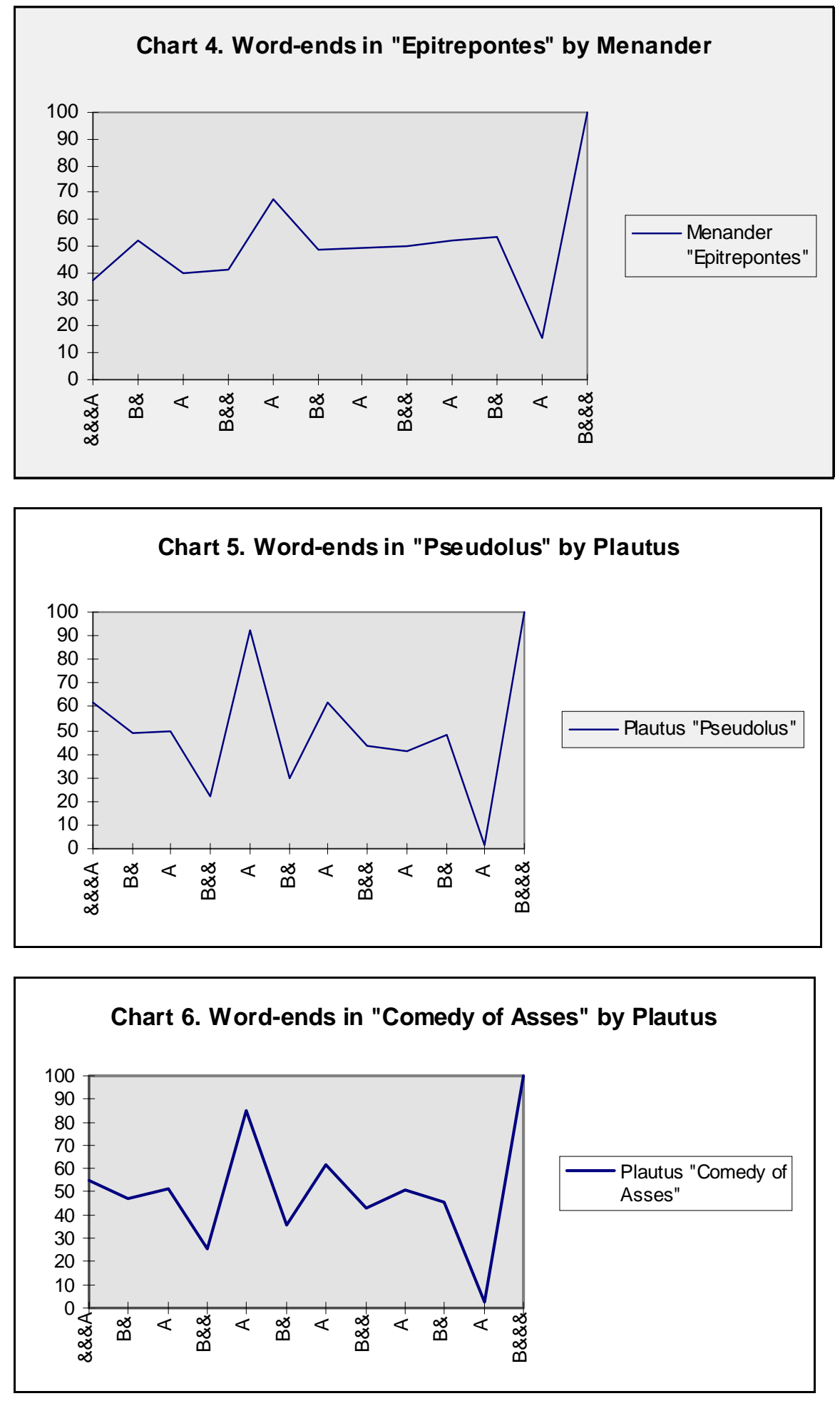

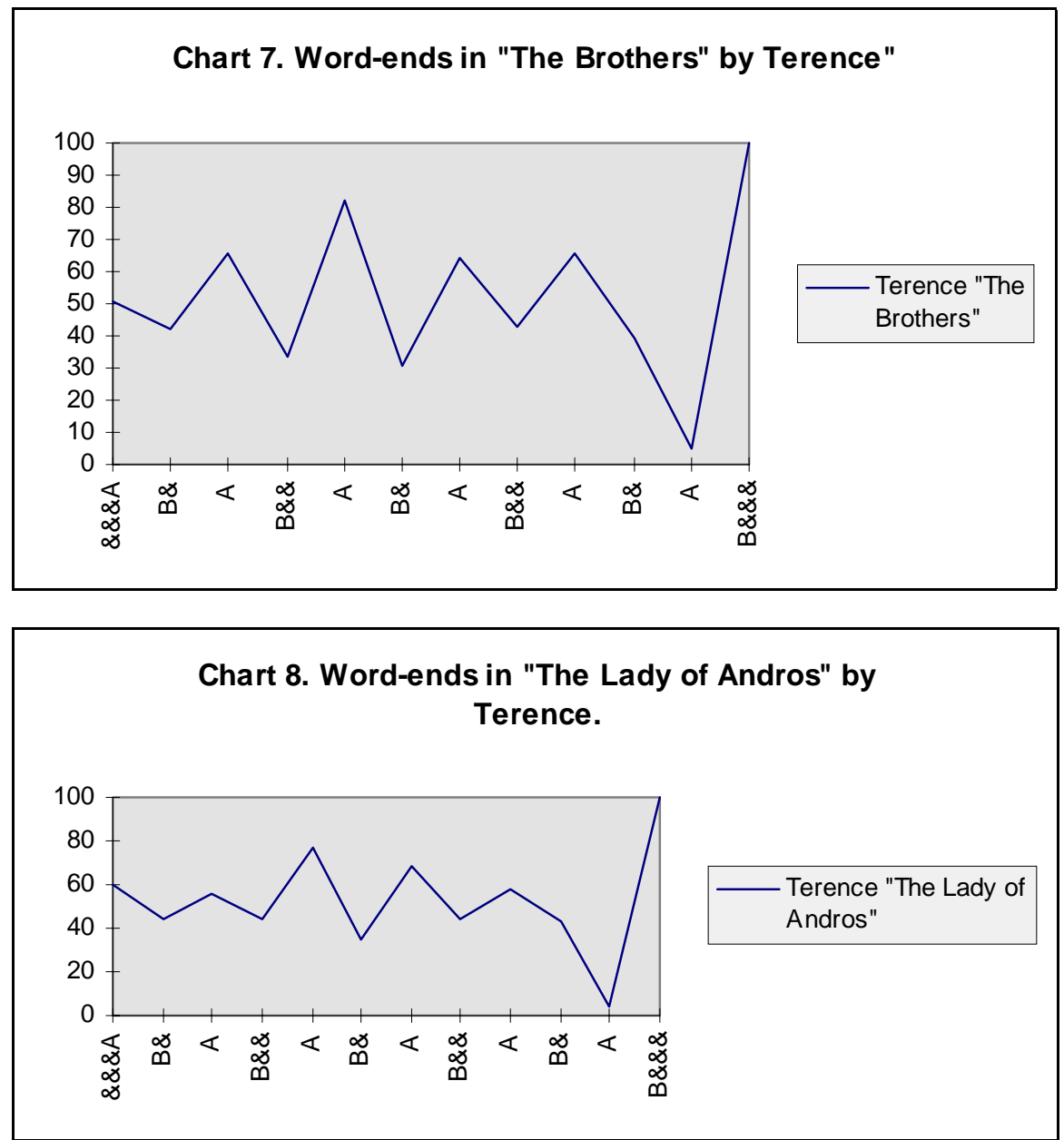